OPEN ACCESS

Edited by:

Laura Airoldi,

University of Padova Chioggia

Hydrobiological Station, Italy

Reviewed by:

Massimo Ponti,

University of Bologna, Italy

Juan Carlos Villaseñor-Derbez,

University of California, Santa

Barbara, United States

*Correspondence:

Mathew A. Vanderklift

mat.vanderklift@csiro.au

tORCID:

Christopher Doropoulos orcid.org/0000-0001-8038-2771

Specialty section:

This article was submitted to

Marine Conservation

and Sustainability,

a section of the journal

Frontiers in Marine Science

Received: 25 May 2020

Accepted: 10 August 2020

Published: 15 September 2020

Citation:

Vanderklift MA, Doropoulos C,

Gorman D, Leal I, Minne AJP

Statton J, Steven $A D L$ and

Wernberg T (2020) Using Propagules

to Restore Coastal Marine

Ecosystems. Front. Mar. Sci. 7:724.

doi: 10.3389/fmars.2020.00724

\section{Using Propagules to Restore Coastal Marine Ecosystems}

\author{
Mathew A. Vanderklift ${ }^{*}$, Christopher Doropoulos ${ }^{2 \dagger}$, Daniel Gorman', Inês Leal ${ }^{1,3}$, \\ Antoine J. P. Minne ${ }^{4}$, John Statton ${ }^{4}$, Andrew D. L. Steven ${ }^{2}$ and Thomas Wernberg, $4,5,6$ \\ ${ }^{1}$ CSIRO Oceans and Atmosphere, Indian Ocean Marine Research Centre, Crawley, WA, Australia, ${ }^{2}$ CSIRO Oceans and \\ Atmosphere, Queensland Biosciences Precinct, St Lucia, QLD, Australia, ${ }^{3}$ Institut des Sciences de la Mer, Université du \\ Québec à Rimouski, Rimouski, QC, Canada, ${ }^{4}$ UWA Oceans Institute and School of Biological Sciences, University \\ of Western Australia, Crawley, WA, Australia, ${ }^{5}$ Department of Science and Environment, Roskilde University, Roskilde, \\ Denmark, ${ }^{6}$ Institute of Marine Research, His, Norway
}

Reversing the decline of coastal marine ecosystems will rely extensively on ecological restoration. This will in turn rely on ensuring adequate supply and survival of propagules - for the main habitat-forming taxa of coastal marine ecosystems these are mainly fruits, seeds, viviparous seedlings, zoospores or larvae. The likelihood of propagule survival - and so restoration success - depends on species- and context-specific knowledge to guide choices about appropriate methods to use. Here, we briefly review life-histories of the main habitat-forming taxa of six coastal marine ecosystems: mangrove forests, tidal marshes, seagrass meadows, kelp forests, coral reefs and bivalve reefs. Restoration of several of these ecosystems has long harnessed the unique properties of propagules, sometimes because they are simple to use (for example, planting propagules of some mangroves), and sometimes because we can draw on knowledge gained from other applications (for example using knowledge of oyster culture to restore bivalve reefs). For other ecosystems, like seagrass meadows, kelp forests and coral reefs, propagules have not yet been widely used, but there is compelling evidence that they can be. Most restoration efforts have used relatively simple techniques, such as manual collection and direct planting or seeding. Some approaches use more complex techniques which include a stage in which propagules are reared in nurseries or aquaria to a size or age at which they are viable, when they are then planted or released at the site to be restored. Other approaches use minimal intervention, and focus instead on providing the conditions that will promote growth from naturally dispersed propagules (such as restoring hydrological conditions to facilitate mangrove recruitment). Future approaches could incorporate knowledge applied from other fields, such as genetics and agriculture, and harness the possibilities provided by technology. Understanding the importance of propagule quality will likely also yield insights, as will effective use of models to help refine restoration methods for testing. Deeper partnerships between practitioners and researchers will help test and develop better methods so that we can learn from each other and strive to improve. Propagules offer multiple promising avenues to expand coastal marine restoration efforts and help achieve global ambitions.

Keywords: bivalve reef, coral reef, kelp forest, larvae, mangrove, seagrass, seeds, tidal marsh 


\section{BACKGROUND}

The health and extent of coastal marine ecosystems dominated by habitat-forming primary producers (mangroves, tidal marsh plants, seagrasses, kelps) and sessile benthic invertebrates (corals, bivalves) has declined substantially on almost all coastlines of the world (Waycott et al., 2009; Ermgassen et al., 2012; Friess et al., 2019; Sully et al., 2019; Wernberg et al., 2019). Although actions to remove or ameliorate causes can arrest this decline, reversing it will rely extensively on ecological restoration. Doing so will also help resolve some of the most intransigent problems that humans face, such as food security, climate change, and susceptibility to natural disasters (Mcleod et al., 2011; Ermgassen et al., 2012; Spalding et al., 2014).

Ecological restoration is needed because individuals of the habitat-forming species often do not manage to arrive or grow in degraded ecosystems, even after the causes of degradation are removed. Such restoration therefore relies on overcoming recruitment limitation - that is, when insufficient new individuals are added to the population through natural processes, either because of low supply or high mortality immediately after settlement (Caley et al., 1996). This in turn relies on ensuring adequate supply and survival of propagules. In some situations, propagule supply might be adequate but recruitment fails because the ecosystem is hostile to settlement, or immediately following settlement. For example, colonization of hard surfaces by algae can prevent successful recruitment of kelps and corals, making recovery difficult after the ecosystem is degradaded (hysteresis: Mumby et al., 2007; Filbee-Dexter and Wernberg, 2018).

The term propagule refers to structures that act to propagate an organism to the next stage in its life-cycle, and can be either sexually produced structures (viviparous or oviparous) such as fruits, seeds and larvae, or clonally produced structures (Table 1 and Figure 1). We consider the dispersal phase as a propagule, regardless of the structure. In some taxa, such as seagrasses, kelps and corals, adult plants or fragments can also be dispersed and we also briefly cover these. Propagules are morphologically distinct from their parents, and in marine organisms they typically have a water-borne dispersal phase; marsh plants also rely on windborne dispersal. Propagules can be viable for a limited period after release, from days to months (e.g., larvae of invertebrates, fruits and seeds of plants), or can be dormant until the right conditions are present (e.g., seeds of some seagrasses and mangroves).

Once settled, survival of individuals to a stage when they in turn can reproduce depends on the presence of conditions necessary for growth, such as food or light, and the absence of negative influences that cause mortality, such as predators, competitors, or physiological stressors (e.g., Doropoulos et al., 2016). Survival and growth can also sometimes be enhanced by the presence of conspecifics, or by symbiotic or mutualistic interactions (Valdez et al., 2020).

Influences on propagule supply and survival usually vary through space and time, which has implications for when, where and how propagules can be used in restoration. The likelihood of propagule survival - and subsequent restoration success - depends on species- and

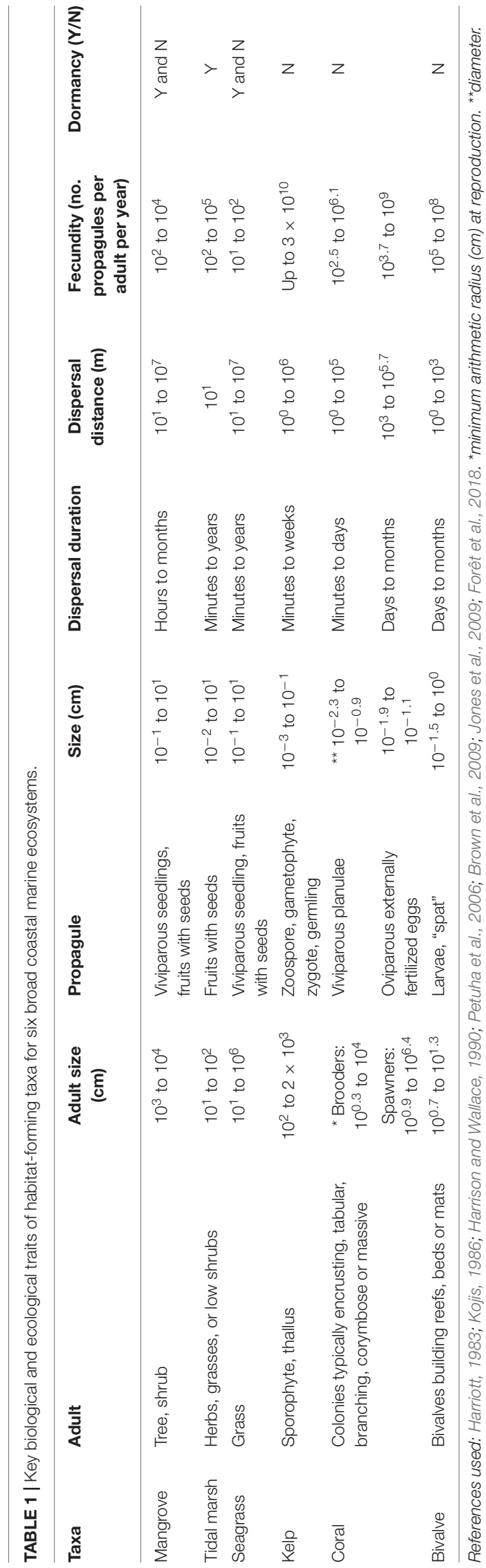



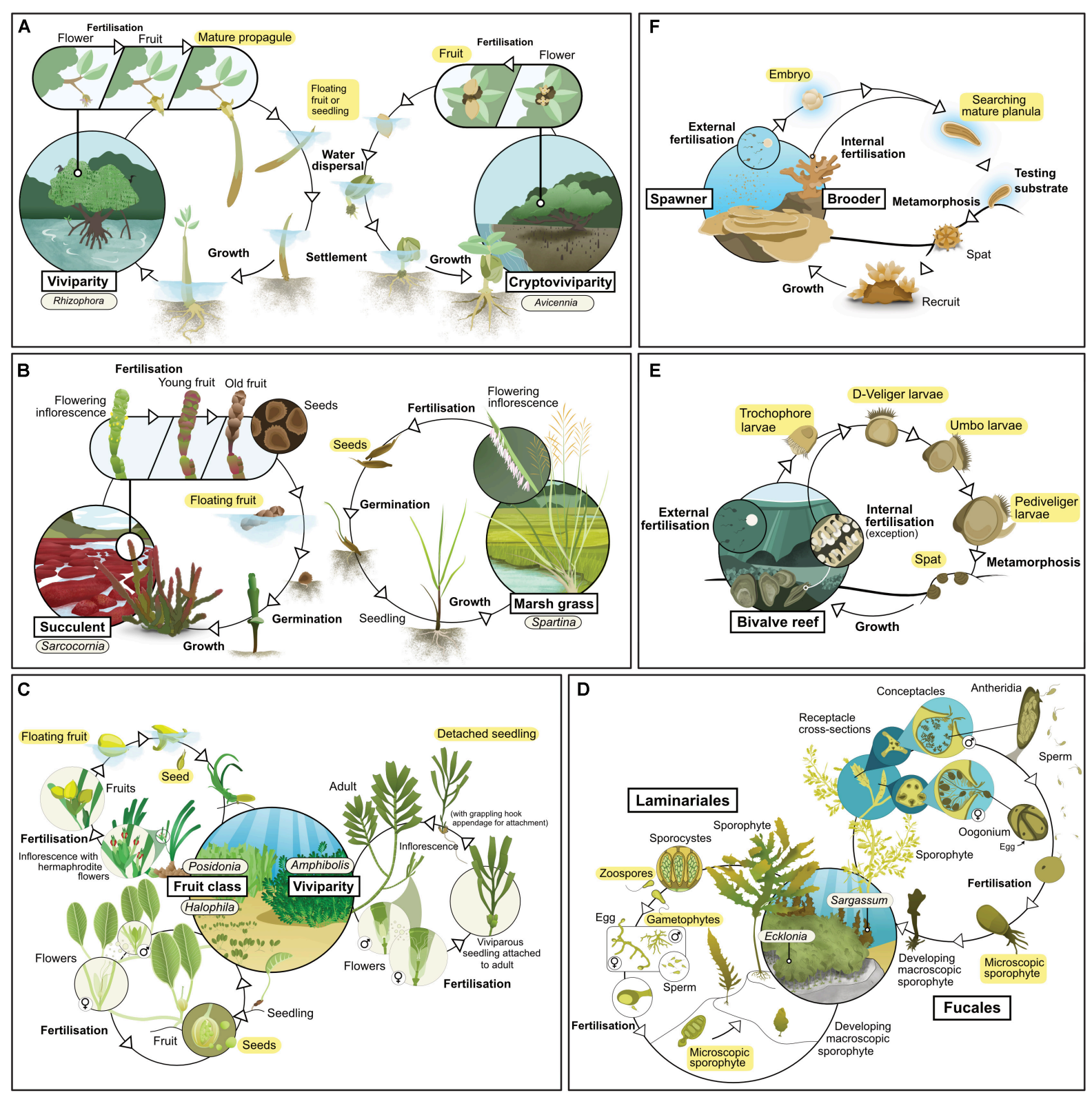

FIGURE 1 | Life history of the main habitat-forming taxa for each of six coastal ecosystem types: (A) mangrove, (B) tidal marsh, (C) seagrass, (D) kelp, (E) coral reef, (F) bivalve reef. Text highlighted in yellow indicates life stages considered as propagules in this review.

context-specific knowledge to guide choices about appropriate methods to use. Understanding whether original causes of decline have been, or can be, sufficiently mitigated is a critical starting point (McDonald et al., 2016). Knowledge about how different types of propagules respond to stressors can help inform this understanding (e.g., Campbell, 2016).

Here, we briefly review life-histories of the main habitatforming taxa underpinning six coastal marine ecosystems: mangrove forests, tidal marshes, seagrass meadows, kelp forests, coral reefs and bivalve reefs. Other coastal ecosystems are also generated by habitat-forming organisms, such as polychaetes, sponges, bryozoans and calcifying algae, and the extent and condition of these are also declining (e.g., Nelson, 2009; Wood et al., 2012; Wulff, 2012; Bruschetti, 2019); we do not review them here, but some of the insights from the six ecosystem we review might also be applicable to those ecosystems. For each ecosystem, we assess the approaches typically used and the significance of propagules for restoration. We also assess some of the major challenges and key science questions, as well as highlight some opportunities and innovations that might help practitioners restore coastal marine ecosystems at rates and extents necessary to achieve a substantial reversal of what we have lost. 


\section{CURRENT STATUS}

\section{Mangrove Forests}

Mangroves are a phylogenetically diverse group of species comprising mostly woody trees and shrubs, but also including some palms and ferns (Duke, 1992). They exhibit a variety of reproductive strategies, although one characteristic that all mangroves share is that their propagules float (at least for a day or two), and so can be dispersed by currents. Some taxa exhibit viviparity, in which an embryo emerges directly from the fruit and develops into a seedling while it is still attached to the parent plant, but many taxa reproduce via fruits with one or more seeds (Table 1 and Figure 1A; Tomlinson, 2016). Mangroves typically rely on propagules for new growth (Kathiresan and Bingham, 2001), a characteristic which indicates that the use of propagules in restoration should yield good results. However, mortality rates of propagules can be high, especially for species with small propagules which are susceptible to predators (Rabinowitz, 1978; Clarke and Kerrigan, 2002).

Mangrove restoration (and afforestation) efforts have long harnessed the potential of propagules, through methods ranging from manual collection and cultivation in nurseries to restoring hydrological regimes and then simply relying on natural dispersal. Indeed, most restoration efforts use propagules, not established plants (such as saplings). Many species have been used in mangrove restoration, but the ease of collecting and planting certain species (such as the viviparous seedlings of Rhizophora) has meant that these have been used more frequently, so the composition of restored mangrove forests is often different to those of undisturbed forests (e.g., Hai et al., 2020). The species chosen often depend on the goals of mangrove restoration efforts; efforts directed at afforestation of newly accreted mudflats, and at planting mangroves as part of silviculture - neither of which are typically considered as restoration - are often dominated by one or just a few species.

Methods of collecting and preparing propagules vary from simple and direct, to more complex and time-consuming. In perhaps the simplest application, seedlings of viviparous species, especially Rhizophora, are collected from the forest floor or water surface, or harvested from adult plants (Chowdhury et al., 2019), and simply inserted directly into the sediment (e.g., Chan et al., 1988). Fruits are often collected in a similar way, the seeds extracted, and sown onto the area to be rehabilitated or planted in nurseries (e.g., Saenger and Siddiqi, 1993). Nursery techniques range from raising propagules in designated nursery beds to growing them with more intensive care in individual units, such as pots or bags (Figure 2a). In each of these approaches propagules are typically raised for months or longer, until they are saplings a meter or more tall (Chowdhury et al., 2019), and they are then transplanted (if grown in a nursery bed), or planted (if grown in pots or bags).

Other approaches do not employ planting, but instead focus on restoring the environmental conditions - especially hydrology - that allow mangroves to recruit naturally. Such methods rely on recruitment from propagules transported by currents, and so harness the dispersal characteristics of mangrove propagules. However, mangrove propagules do not appear to be dispersed passively, but are able to adjust both buoyancy and root initiation (Wang et al., 2019), traits which probably influence how they colonize restored areas. Methods restoring hydrological conditions have yielded good results in some places, with species composition of mangroves approaching that of undisturbed mangrove forests (e.g., Cameron et al., 2018).

Rates of survival of mangrove propagules during restoration is highly variable. Robust experimental tests of methods are still few, and although there are multiple guides for mangrove restoration (e.g., Primavera et al., 2012; Lewis and Brown, 2014), there is still much room for researchers and practitioners to work together to develop reliable methods. Given rates of restoration still do not keep pace with the rates of habitat degradation and loss, restoration may need to harness innovations such as tissue culture and propagation of rare or recalcitrant species (Eganathan et al., 2000), or use of remotely operated vehicles to disperse (or even plant) propagules.

Sea level rise will also pose a challenge to mangrove restoration in some places, as some mangroves become inundated more frequently, and for longer (Lovelock et al., 2015) or temperature thresholds at equatorward range limits are exceeded. More proactive efforts to establish mangroves in places where they do not currently exist, such as the landward edge of forests, might also be needed. Use of propagules will likely be central to these efforts.

\section{Tidal Marshes}

Tidal marshes (sometimes also known as saltmarshes) occupy the upper intertidal zone of many tropical, temperate and even polar coasts (Allen and Pye, 1992). These ecosystems comprise stands of salt-tolerant plants (halophytes) with a wide phylogenetic diversity that includes herbs, grasses, sedges and rushes, and small shrubs (Table 1). A key characteristic is that they are regularly flooded by tides (Adam, 1990).

Tidal marsh plants have a range of different life histories and dispersal mechanisms (Table 1 and Figure 1B). Some species, such as those from the genus Spartina, can survive and expand through rhizome elongation (Pennings and Callaway, 2000), but most species rely on sexual reproduction and recruitment from seeds (Richards et al., 2004). Succulent taxa produce flowers that are pollinated by insects to produce seed-bearing fruit throughout the year. Once released, these fruits float on the water, and can be dispersed over distances of up to thousands of kilometers (Huiskes et al., 1995). Grasses, rushes and sedges tend to have hollow stems, sheath-forming leaves and windpollinated flowers arranged in spikelets. Their seeds are also widely dispersed by tidal currents, as well as by wind (Soons, 2006), small herbivores (Chang et al., 2005) or on the feet and feathers of waterfowl (Viviansmith and Stiles, 1994).

Restoration of tidal marshes tends to involve reintroducing tidal flow, transplanting large tussocks (or "sods") cut from adjacent saltmarsh and the direct planting of nursery-reared seedlings (germinated from collected seeds). The earliest large-scale restoration efforts relied on a combination of planting and/or transplantation of seedlings or tussocks (Spurgeon, 1998; Milano, 1999). Subsequent large-scale (>2,000 ha) restoration 


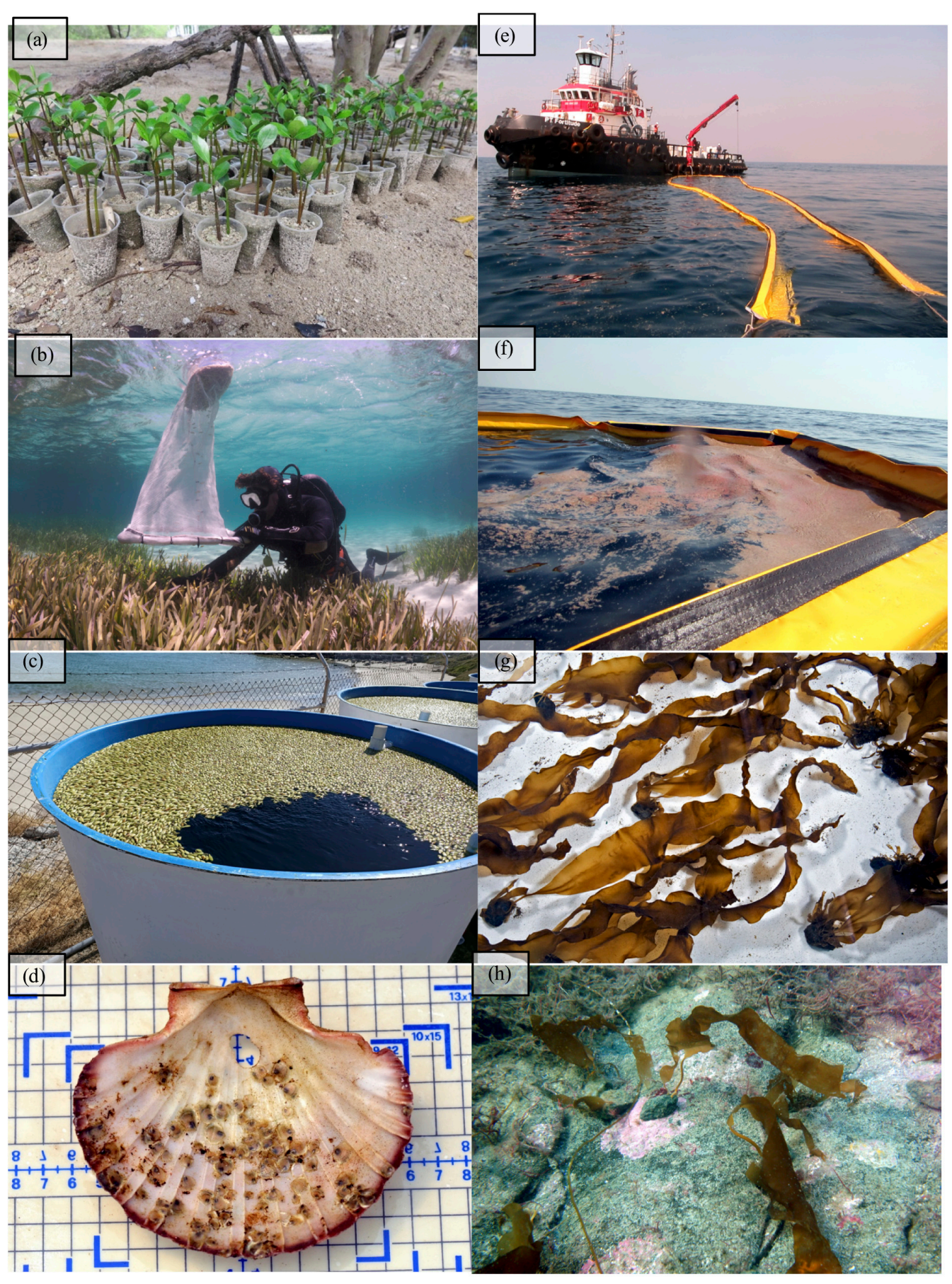

FIGURE 2 | Examples of how propagules are prepared for restoration: (a) Viviparous seedlings of Rhizophora grown in plastic pots prior to planting; (b) collection and (c) preparation in tanks of Posidonia australis fruit; (d) flat oyster (Ostrea angasi) spat attached to an empty shell for deployment; (e,f) collection of coral spawn using an oil boom; (g) young sporophytes of kelp (Saccharina latissima) seeded onto small rocks ("green gravel") in the laboratory and (h) sporophytes outplanted to a rocky reef. Photo credits: (a) M. Vanderklift, (b) J. Statton, (c) K. Dawson, (d) Victorian Shellfish Hatchery, (e,f) Christopher Doropoulos, (g) S. Fredriksen/K. Filbee-Dexter, (h) S. Fredriksen. Images d and e reused under a Creative Commons CC-BY license from Doropoulos et al. (2019b).

of marshes by planting seedlings propagated from seeds has subsequently been achieved (Adams and Benosky, 1998). In contrast, few restoration efforts have involved direct seeding, with the best examples having been achieved for Spartina alterniflora with seeds being distributed by boats and even aircraft (Broome et al., 1988; Benedict et al., 2012). These studies found that seed should be harvested as near as possible to maturity, or just prior to splitting, with harvesting done by hand or using 
machinery (Broome et al., 1974). Harvested seed can be stored for months and concentrated using a thresher designed for small grain (Broome et al., 1988). More recently, direct seeding has been used in conjunction with other planting methods for several projects in Australia (Department of Environment and Climate Change, 2008). Direct seeding in this way allows a larger area to be restored (Knutson, 1977).

Few quantitative studies have contrasted the outcomes of direct seeding with other approaches (planting and transplanting). Broome et al. (1988) reported similar aboveground biomass accumulation after two years between a location that was seeded by hand and a location that was planted with sprigs at a similar density at the same time. Germination success was improved by preparing the substrate through weed removal (Broome et al., 1988), burning and mechanical tillage (US Environmental Protection Agency, 1979) and by investing in activities such as fencing to exclude animals. Although there have been several recent studies comparing the survival rates of corm shoots and rhizomes with larger transplantation units such as tussocks (Ge et al., 2019; Zhang et al., 2020), these do not fit our definition of propagule. Seed dispersal distances for some tidal marsh species can be limited (e.g., only a few meters for Spartina), and lateral expansion of clonal fragments is restricted to existing marsh, so manual seeding might help to restore isolated areas where naturally dispersed seeds and clonal growth would not otherwise reach.

While seeding is yet to be widely adopted in tidal marsh restoration projects, the ability to restore large areas (tens of hectares) has been demonstrated. Agricultural equipment can be used to rapidly and efficiently gather seed. Industrial threshers can concentrate seed, making the process of storage, transport and seeding more efficient. Collected seed can be dried, fed through an agricultural combine to remove large stems and leaves, and stored at an appropriate temperature (typically below $4^{\circ} \mathrm{C}$ ). Another promising option is the direct application of seed using machinery. Possible future solutions to restoring large areas of tidal marsh could involve aerial methods being developed for terrestrial systems that employ drones, automation and digital intelligence (Sturmer, 2017).

\section{Seagrass Meadows}

There are four lineages of seagrasses (Les et al., 1997) containing relatively few species (all in a single order of monocotyledon). They occupy shallow environments on all continents except Antarctica (Short et al., 2007): their distribution also extends to the High Seas, such as on the Mascarene Plateau. Sexually and asexually produced propagules are important for dispersal (Table 1 and Figure 1C). Species from the genera Amphibolis and Thalassodendron produce viviparous seedlings (Kuo and den Hartog, 2006). Most others produce seeds, although their characteristics vary widely (Kendrick et al., 2012); some species produce seeds or fruit that are positively buoyant and have potential for long-distance dispersal (e.g., Enhalus, Posidonia, and Thalassia). Others produce seeds that are negatively buoyant with limited dispersal potential (e.g., Zostera and Halophila) (Lacap et al., 2002; Kendrick et al., 2012), although long-distance dispersal can still occur via transport of detached fragments carrying spathes (modified leaves which enclose the flower cluster; e.g., Zostera spp., Harwell and Orth, 2002). Nearly all species are also capable of asexual reproduction through rhizome elongation (Kendrick et al., 2017) or the production of asexual fragments (e.g., rhizome fragments, pseudoviviparous plantlets) (Ballesteros et al., 2005; Sinclair et al., 2016). Sexually derived propagules of some species lack the ability to be dormant (e.g., Amphibolis and Posidonia), while others can remain dormant for long periods (Inglis, 2000; Orth et al., 2000). These differences in biology and ecology of propagules strongly influence patterns of recruitment and dispersal, and the way we can use them effectively in restoration.

Seagrass restoration has primarily involved using asexual material (e.g., cuttings, rhizome fragments or cores) collected from donor meadows. Relatively few seagrass restoration efforts have used sexually derived propagules (Statton et al., 2012; van Katwijk et al., 2016). The infrequent use of sexually derived propagules is probably in part due to the temporal and spatial variability of seed availability (Orth et al., 2006), as well as the perception that survival rates of seeds and seedlings are poor (Fonseca, 1998; Kirkman, 1999). Although survival rates are often low, recent reviews of seed-based research highlight that this is probably because of limited knowledge about availability and collection of quality seed, skills in seed handling and delivery, and suitability of restoration sites (Orth et al., 2000; Statton et al., 2012; van Katwijk et al., 2016; Kendrick et al., 2017).

Methods for collecting and preparing propagules vary according to their characteristics and typically harness their natural dispersal mechanisms. For example, for viviparous taxa such as Amphibolis, recently detached seedlings can be collected by placing fibrous and weighted material, such as sand-filled hessian bags, which the seedlings' grappling structures attach to as they drift past. In this way thousands of seedlings can be captured in less than a square meter (Tanner, 2015). Typically, sandbags are deployed in locations where restoration is required, and are not collected and re-deployed elsewhere.

For species which have seeds contained within spathes (e.g., Zostera spp.), these can be harvested using divers or mechanical harvesters (Orth et al., 2012). In Chesapeake Bay (United States) several million Zostera marina seeds have been collected each year during the peak reproductive season (May-June) since the early 2000's using a mechanical harvester (Orth et al., 2012). Seeds are extracted from spathes after harvesting, but the methods of extraction and delivery vary. For example, some methods involve keeping the spathes within large holding tanks where they eventually split open and release the (negatively buoyant) seeds, which are then collected from the tank bottom (Orth et al., 2012). The seeds are then placed in a flume to determine seed quality based on settling velocity, after which they are scattered by hand from boats over recipient habitats (Orth et al., 2012). Alternatively, using buoys anchored in place, $Z$. marina spathes can be suspended over restoration sites in mesh bags; the spathes release and deliver the seeds to the seafloor (Pickerell et al., 2005).

For species that release seeds from fruits that float (Posidonia spp., Halophila spp.), fruits can be detached from the parent plant by shaking; they then float to the surface where they are 
collected in nets (Statton et al., 2013, 2017; Figure 2b). Seeds are then extracted from the fruit via vigorous aeration and water movement from pumps at stable temperatures $\left(25^{\circ} \mathrm{C}\right)$ within tanks (Figure 2c). The negatively buoyant seeds are then collected from the tank bottom and scattered by-hand over recipient habitats. Other methods have been trialed with limited success, including direct planting of seeds by hand, injecting seeds using machinery, or planting and deploying within hessian sandbags.

Restoration using seagrass propagules has so far demonstrated low and variable outcomes, with more than $90 \%$ of propagules failing to survive (Orth et al., 2003, 2007; Tanner, 2015). For propagules to be successfully incorporated within seagrass restoration programs, there will need to be a reduction in propagule wastage (which includes mortality, but also failure to germinate or dispersal away from the restoration site), to facilitate higher rates of germination and survival. A major barrier to effective use of seeds in seagrass restoration is our knowledge about seed quality. Seed quality encompasses aspects such as viability, size (which can confer energy reserves available for initial growth and establishment), damage to the seed coat or seedling, bacterial infection, genetic diversity and ecotype (which may influence a seeds ability to respond to the restoration environment).

Nevertheless, the diversity of propagules and species used in restoration is increasing and our understanding of seagrass seed biology and ecology is advancing (Moore et al., 1993; Orth et al., 2000; Tanner, 2015; Statton et al., 2017; Strydom et al., 2017). The practical use of this knowledge to enhance restoration success is also improving, albeit slowly. To increase the chances of propagule establishment, we need better understanding about the steps that precede seed delivery to restoration sites, including seed quality (e.g., see Orth et al., 2000), as well as the environmental and social barriers that influence survival and growth.

\section{Kelp Forests}

Kelp forests are dominated by large habitat-forming seaweeds ("kelp") from the orders Laminariales and Fucales (Wernberg and Filbee-Dexter, 2019). Laminarian and fucalean kelp have distinct life histories (Table $\mathbf{1}$ and Figure 1D). Fucalean kelp have direct development, in which eggs are fertilized on the parent plant, which subsequently releases a relatively large $(\sim 0.1 \mathrm{~mm})$ zygote; this generally disperses a short distance from the parent before settling (centimeters to meters; Kendrick and Walker, 1991; Gaylord et al., 2002). In contrast, laminarian kelp have a more complex life cycle which alternates between a microscopic gametophyte and a macroscopic sporophyte. The macroscopic sporophyte releases zoospores which can disperse across distances that range from a few meters to kilometers from the parent (Reed et al., 1992; Gaylord et al., 2002). Once settled, the zoospores grow into male and female gametophytes, which must settle within a millimeter from one another for successful fertilization (Reed, 1990). Many species of kelp have vesicles, allowing them to float on the surface; floating fertile adults can increase dispersal distances by several orders of magnitude (e.g., Hernández-Carmona et al., 2006). Both laminarian and fucalean kelps are hyper fecund. For example, a single Ecklonia maxima kelp sporophyte can release more than 30 billion zoospores per year (Joska and Bolton, 1987) and even a small individual of Sargassum muticum can release around half a million zygotes (Norton and Deysher, 1989).

High fecundity, efficient dispersal and fast growth are all traits that should enable kelps to recolonize extensive areas from a few reproducing parents if suitable conditions exist for survival and growth. There have been multiple efforts to regrow lost or declining kelp forests (reviewed in Layton et al., 2018; Bekkby et al., 2020; Fredriksen et al., 2020), typically through either assisted recovery, in which the focus is on restoring conditions favorable for survival and growth, or active restoration in which kelps are reintroduced to target areas.

Protection from urchin predators (through restrictions on fishing or hunting), direct removal of kelp predators (such as sea urchins) and sewage and catchment management have allowed kelp forests to regrow in some places after subsequent improvements in water quality (Foster and Schiel, 2010). However, hysteresis associated with transition of kelp forests to turf seascapes during eutrophication means that this is not always possible (reviewed in FilbeeDexter and Wernberg, 2018), and so assisted recovery is often needed. Assisted recovery can also include afforestation by introducing kelps to places they did not grow previously, including artificial reefs, to replace kelp forest substrate lost to urban development (Terawaki et al., 2001; Deysher et al., 2002).

Kelp restoration typically involves transplanting adult or subadult kelp from donor wild or cultured populations, attaching them either directly to the reef or to artificial structures (e.g., Wilson and North, 1983; Hernández-Carmona et al., 2000; Falace et al., 2006; Haraguchi et al., 2009; Campbell et al., 2014). Kelp grow on hard surfaces and are not easily attached, so sometimes this requires labor-intensive drilling or installation of attachment surfaces (reviewed in Fredriksen et al., 2020; Layton et al., 2020). Propagules (spores, gametophytes, zygotes or germlings) have not been widely used. While it is relatively easy to extract kelp zoospores and zygotes in the laboratory (e.g., Alsuwaiyan et al., 2019), they are very small (Table 1), highly sensitive to environmental conditions (including desiccation) and cannot easily be planted or scattered. These traits make it difficult to collect, transport, store and grow kelp propagules.

Indirect introduction of propagules to surmount the problem of recruitment limitation has been done by translocating fertile reproductive tissues (sporangia and receptacles: HernándezCarmona et al., 2000; Falace et al., 2006; Gorman and Connell, 2009; Haraguchi et al., 2009; Verdura et al., 2018). This approach fails where established algae such as turfs prevent the settlement of propagules (e.g., Filbee-Dexter and Wernberg, 2018). Consequently, several studies have explored seeding of propagules onto natural or artificial substrates in tanks, which were subsequently out-planted with some success (Falace et al., 2018; Fredriksen et al., 2020; Figures 2g,h). Other studies have planted cultured or wild-collected small juveniles, but they tend to succumb to high mortality or yield limited long-term success (Hernández-Carmona et al., 2000; Carney et al., 2005). 


\section{Coral Reefs}

Scleractinian corals comprise approximately 2,400 extant species, all in a single order (Scleractinia: Veron, 2013). They encompass a wide variety of morphologies (Madin et al., 2016), which can vary in response to the surrounding environment, such as the physical forces exerted by waves (Todd, 2008). Corals can fragment, and some of those fragments are able to attach and develop into new colonies through clonal growth; this is a common strategy for short-distance asexual dispersal and colonization, especially by branching corals (Highsmith, 1982).

Corals' ability to regrow from fragments has been harnessed for restoration. Transplanting colonies and fragments was tested as early as 1971 in Hawaii (Maragos, 1974) and has been used in more than $80 \%$ of coral restoration projects (BoströmEinarsson et al., 2020). The approach is simple and fragments often have high survival rates, yielding rapid increases in the percentage cover of living coral (e.g., Ladd et al., 2019; Williams et al., 2019). It does, however, have limitations: it is labor intensive, relies on access to sufficiently abundant donor colonies or fragments, and is generally limited to branching corals (Edwards and Clark, 1999; Edwards, 2010; Ladd et al., 2019). Some studies have therefore focused on generating more rapid attachment methods (e.g., Suggett et al., 2020) or on growing corals in nurseries to minimize reliance on wild colonies (e.g., Shafir et al., 2006). Recent "microfragmenting" techniques, in which small fragments $\left(<1 \mathrm{~cm}^{2}\right)$ of the same species and genotype are placed close together to more rapidly reach larger sizes by fusing with neighboring fragments have also been developed for slow-growing, massive corals (Page and Vaughan, 2014).

All coral taxa use sexual reproduction to produce larvae (Table 1). Corals are broadly categorized according to two modes of sexual reproduction - brooders and spawners - each with particular life-history strategies (Table 1 and Figure 1e). Brooding corals reach maturity at small colony sizes $\left(\sim 2 \mathrm{~cm}^{2}\right)$, develop their larvae within the parent colony, and release large, competent (i.e., able to undergo metamorphosis) larvae throughout the year. Released larvae are able to attach and metamorphose immediately, so dispersal distances from the parent colony can be short $(<1 \mathrm{~m})$. In contrast, spawning corals release orders of magnitude more eggs and sperm into the water column, but only in one or two synchronous mass spawning events each year; the eggs are then fertilized and develop into larvae over days to weeks, during which time they can disperse up to hundreds of kilometers. Thus, spawning corals offer opportunities for mass production of larvae for restoration, while brooding corals offer opportunities for transplanting reproductive colonies.

Despite the potential to transplant brooding corals to enhance local propagule supply, this approach has received little attention, and where it has been conducted subsequent increases in coral abundance have been small or absent (Maida et al., 1995; Ferse et al., 2013; Montoya-Maya et al., 2016). Although the evidence remains equivocal, there is potential to transplant colonies of brooding corals to act as a local source of propagules. However, the ability to use this method to restore large areas is likely to be limited for similar reasons as transplanting coral fragments - it is labor intensive and applicable to few taxa.

Most coral taxa (63\%) are hermaphroditic spawners (Baird et al., 2009). Restoration methods that harness their immense supply of propagules has been conceptualized for decades (Rinkevich, 1995; Figures 2e,f) but is challenging in practice because they release gametes only once or twice a year (Babcock et al., 1986), the formation of aggregations of spawn depends on local weather and currents (Oliver and Willis, 1987), and mortality of coral spawn is high (Pollock et al., 2017; Doropoulos et al., 2019b). In some experiments that have sought to overcome these constraints, spawn were collected and reared to larvae in situ in floating ponds; larvae were then pumped directly from these ponds into enclosures attached to the reef or settled onto biologically conditioned artificial substrata such as tiles or aragonite plugs, which are placed onto reefs or back into nurseries for continual production (Heyward et al., 2002; Omori and Iwao, 2014; Omori, 2019). Other experiments have variously involved bringing reproductive colonies to a land-based facilities for gamete collection and fertilization, and either settling larvae onto artificial substrates that are then placed onto reefs (Guest et al., 2014; Edwards et al., 2015; Baria-Rodriguez et al., 2019), or directly releasing larvae into mesh enclosures placed on the reefs (de la Cruz and Harrison, 2017). In one experiment, larvae released directly into mesh enclosures grew into reproductive adult colonies (de la Cruz and Harrison, 2017). In others, increased rates of larval settlement were recorded on settlement tiles in places where reared larvae were released, but there were no subsequent differences in juvenile coral abundance compared to control areas (Edwards et al., 2015).

Some restoration efforts have focused on providing the substrate that coral larvae settle on. In one type of application, low voltage electrical currents are used to encourage precipitation of minerals (aragonite, brucite), which are then colonized by encrusting coralline algae (e.g., Goreau and Prong, 2017). These algae in turn exude chemical compounds that are used by larvae as settlement cues: however, not all coralline algae exude these chemicals, which might explain why this approach can yield either positive or negative effects on the settlement, growth and survival of coral propagules (e.g., Chavanich et al., 2014; Goreau, 2014).

Demographic modeling suggests that restoration of up to $10^{5}$ adult colonies is feasible by harvesting wild coral-spawn slicks and developing these in large vessels, with minimal impact to wild populations (Doropoulos et al., 2019a). An initial pilot study on the Great Barrier Reef (Australia) yielded 400 times more larvae than predicted by a model (Doropoulos et al., 2019b), due to much greater densities of gametes found in coral spawn-slicks than previously recorded in the literature, and higher survival rates of gametes than anticipated.

\section{Bivalve Reefs}

Reefs built by and from bivalves such as oysters and mussels (commonly referred to as "shellfish reefs") were once common along sheltered coasts around the world (Harding and Mann, 2001), but they now occupy only a small proportion of their historical distribution (Beck et al., 2011). These reefs can 
occur in subtidal and intertidal habitats, and can comprise one or multiple species (for instance Ostrea angasi often cooccurs with Mytilus galloprovincialis or Pinna bicolor, forming "Angasi reefs" in southern Australia). There are more than 9,000 extant species of bivalves, but most reefs are formed by species from two families, Mytilidae (mussels) and Ostreidae (oysters). Most species of bivalves have separate sexes (i.e., they are dioecious) and many change sex during their lifetime (i.e., they are sequential hermaphrodites). Gametes (eggs and sperm) are released into the surrounding water where fertilization occurs, and planktonic veliger larvae are formed (Table $\mathbf{1}$ and Figure 1F). These larvae remain planktonic for a period that ranges from days to weeks, until they perceive an external cue (such as chemicals exuded by biofilm, Toupoint et al., 2012; or nutrient availability, Toupoint et al., 2012; Leal et al., 2018), upon which they settle onto the bottom and metamorphose. This bottom-dwelling early stage is known as "spat." Oyster spat ( $<25 \mathrm{~mm}$ shell height; Powers et al., 2009) grow attached to one another, forming complex reefs after multiple generations (Hargis and Haven, 1999). Mussel spat can change position by manipulating the byssal threads they use to attach and by secreting mucus threads ("byssus-drifting;" Sigurdsson et al., 1976). Such migrations after settlement can move them away from the places they originally settled.

Restoration of bivalve reefs has harnessed the long history of bivalve aquaculture. Two broad strategies are typically employed: adding adults ("broodstock"), and adding wildharvested or hatchery-reared spat. A combination of both strategies is often used, often following addition of stones and shells (known as "cultch") as an initial substrate (Coen and Luckenbach, 2000). Densities of juvenile spat used in restoration projects range from 350,000 per hectare (e.g., Windara Reef, South Australia; Robertshaw et al., 2019) to 5 million per hectare (e.g., Chesapeake Bay, United States; Allen et al., 2013). Hatcheries usually produce larvae from adults in tanks, and keep them in large tanks with water and cultch to allow the larvae to attach ("spat-on-shell;" Figure 2d). Some hatcheries may produce unattached larvae, which are easier to transport than spat-on-shell because larvae occupy a smaller volume (Westby et al., 2019), and larvae are "seeded" into suitable habitats (Gillies et al., 2017). Transporting unset larvae can yield high mortality rates (Westby et al., 2019). Restoration of bivalve reefs can also take advantage of other innovations developed through bivalve aquaculture, potentially including selective breeding (de Melo et al., 2016).

Encouraging recruitment of natural spat by placing cultch in a place with a high abundance of larvae can be an alternative: especially because mortality of hatchery-produced spat can be high (30-50\% over 6 months post-deployment, and up to $85 \%$ during the first year: Gillies et al., 2017; Westby et al., 2019). In one study, 7 out of 11 (64\%) bivalve reefs restored with cultch, relying only on natural recruitment, were successful (Powers et al., 2009); recruitment in the first year reached 30-40 spat $\mathrm{m}^{-2}$, particularly in restored reefs located nearby tidal marshes. Facilitation of Ostrea angasi recruitment by canopy-forming kelp Ecklonia radiata in southern Australia also suggests that harnessing knowledge about linkages between habitats in design of shellfish restoration projects might also improve outcomes (Shelamoff et al., 2019).

Bivalve larvae can disperse up to hundreds of kilometers (Petuha et al., 2006; Table 1). Water currents and substrate (such as whether the seafloor is sediment or rock) can strongly influence larval retention and recruitment (Breitburg et al., 2000; Mann, 2000; Brumbaugh et al., 2006). Restoration using cultch aims to harness this by providing substrate to encourage larvae to settle. Knowledge of currents and larval dispersal will likely facilitate selection of sites where larvae are likely to be present in sufficient abundance.

\section{FUTURE OPTIONS}

Ecological restoration is attracting considerable interest as part of a portfolio of nature-based solutions to some of our most intractable and global problems, like food security and climate change (Cohen-Shacham et al., 2016). This ambition is sometimes expressed as targets which set a particular areal extent of an ecosystem to restore, although this can incentivize practices that are contrary to the underlying motivation (Seddon et al., 2020). So, when considering how we might use propagules to assist in ecological restoration, we should bear in mind the underlying ambition, and expressly frame goals that are congruent with this.

Restoration practitioners working in some ecosystems have long used propagules, sometimes because they are the simplest and easiest approach (for example harvesting and planting viviparous seedlings of mangroves from the genus Rhizophora), and sometimes because we can draw on knowledge gained from other applications (for example from oyster aquaculture). These efforts have at times allowed restoration of large areas (e.g., Hai et al., 2020). For other ecosystems, like seagrass meadows, kelp forests and coral reefs, propagules have not yet been widely used, but there is compelling evidence that they can be. Transferring the lessons learnt among ecosystems will likely help practitioners restore larger areas more effectively.

Most restoration efforts have used relatively simple techniques, such as manual collection and direct planting or seeding. Some approaches use more complex techniques which include a stage in which propagules are reared in nurseries or aquaria to a size or age at which they are viable, when they are then planted or released at the site to be restored. Other approaches use minimal intervention, and focus instead on providing the conditions that will promote growth from naturally dispersed propagules (such as restoring hydrological conditions to facilitate mangrove recruitment, or deploying substrate to facilitate settlement of bivalve or coral larvae). Using propagules offers the possibility to expand the spatial extent of restoration efforts; for the same amount of labor, a greater area can be restored. They might also offer the possibility to improve the quality of outcomes, for example by allowing more species to be included. To design restoration actions that are most likely to meet the goals, it will be important to understand how the choice 
of activity influences the trajectory of the restored ecosystem. There are few comparisons for marine ecosystems that allow such comparisons, but experimental tests in terrestrial forests have demonstrated differences between naturally regenerating and planted forests (Li et al., 2018; Caughlin et al., 2019; Staples et al., 2020).

Incorporating technology - new and old - into development of propagule-based restoration will also yield better outcomes. Such technology could encompass multiple stages from collection of propagules to rearing them in tanks or nurseries, and finally dispersing them at the site to be restored. For example, large vessels and booms have successfully been used to collect wild coral-spawn slicks and culture them to viable larvae (Doropoulos et al., 2019b), and tank-based techniques have been used to induce settlement of kelp spores onto gravel which is then scattered onto reefs (Fredriksen et al., 2020). Similarly, with tidal marshes the application of mechanized approaches (for seed collection as well as seeding) and processes that concentrate and efficiently store seed can lead to greater efficiencies in the use of propagules when compared to nursery rearing of seedlings and direct planting. Autonomous air-, water- or land-based vehicles can be developed to harvest or disperse propagules. Innovative applications of chemistry and manufacturing, such as development and production of substrates with chemical cues that induce settlement could harness natural dispersal to enhance restoration outcomes. Incorporating knowledge of microbiomes, including by inoculating either propagules or substrates, could enhance survival rates.

Modern genetics holds many opportunities to address the challenge of environmental change and increase the success of restoration efforts through a range of techniques from selective breeding and assisted adaption to fully synthetic biology (van Oppen et al., 2017; Coleman and Goold, 2019). Selective breeding, and perhaps even genetic modification, can help develop genotypes with a greater likelihood of survival under novel contemporary conditions, or even likely future conditions. Although these techniques have long been used in agriculture and forestry, they have not yet been widely adopted in marine restoration (but see Camara and Vadopalas, 2009). This approach has a set of attendant risks, such as the possibility of inadvertently selecting for genotypes that perform better in nurseries or hatcheries than they do in nature. Nevertheless, it offers the possibility to develop restoration methods that can more precisely achieve some goals, or that are better able to survive in changing conditions (Coleman et al., 2020). This endeavor should involve meaningful dialog between researchers and practitioners, as well as ethicists and others, to guide research that is ethical as well as pragmatic. Key research questions center on the nexus between restoration and adaptation, application of technology and modern genomics, and the practicalities of restoring large areas. Understanding will be advanced from traditional fields of inquiry like ecology, but efforts should also draw on insights from other fields, such as the long history of selective breeding for agriculture, which has shown that selection for specific traits can lead to a decrease in fitness of a population (Goddard, 2009).
Many restoration efforts are conducted by researchers in an explicit experimental framework; many others are essentially uncontrolled experiments, in the sense that they implement practices that are based on ideas generated from some knowledge of biology and ecology. There is much we can learn from the latter, and deeper partnerships between practitioners and researchers will help harness this so that we can learn from each other and strive to improve. These partnerships might take different forms, and should be sensitive to the varying needs of practitioners. In some situations, simple conversations might be most appropriate, but in others integrating restoration efforts as formalized tests of hypotheses about restoration methods, such as contrasting results between places left to regenerate from natural recruitment with places where accelerated recruitment is achieved through deploying propagules, would be of substantial value. Indeed, such efforts already occur.

This dialog can include the settings in which restoration is typically effective, or not. High mortality is common in restoration efforts, often from inappropriate site selection, or failure to remove the underlying causes of degradation. Understanding the importance of propagule quality will likely also yield insights: quality can encompass traits such as viability, size (which can reflect energy reserves available for initial growth and establishment), damage, bacterial infection, genetic diversity and provenance (reflecting origin and diversity: Coleman et al., 2020). The traits may each influence a propagule's ability to survive and grow in the conditions it is subjected to. Continued learning will be facilitated by understanding the situations in which survival is high, from propagule trait to site condition.

Researchers can also use modeling tools to help refine restoration methods for testing. Although this has been done to some extent (Doropoulos and Babcock, 2018), there is much scope to expand it. Combining various combinations of models (such as hydrodynamic models with demographic, physiological or ecological models) is likely to benefit restoration practice by identifying some of the most promising methods to try.

In each of the ecosystems reviewed here, propagules have the potential to yield successful restoration across spatial extents larger than those possible by transplanting older life stages. For some ecosystems their potential has long been harnessed. To achieve global ambitions for restoration, and take advantage of the possibilities it offers for nature-based solutions, innovations and partnerships that help refine and expand efforts are needed.

\section{AUTHOR CONTRIBUTIONS}

MV and AS conceived the concept. MV, CD, DG, IL, JS, AS and TW wrote the manuscript. AM prepared the illustrations. All authors contributed to the article and approved the submitted version.

\section{ACKNOWLEDGMENTS}

TW was supported by the Australian Research Council Discovery Project DP190100058. 


\section{REFERENCES}

Adam, P. (1990). Saltmarsh Ecology. New York, NY: Cambridge University Press.

Adams, C. S., and Benosky, C. P. (1998). "2,400 hectares of salt marsh wetland restoration," in Proceedings of the 1998 ASCE Wetlands Engineering River Restoration Conference, Denver, CO.

Allen, J. R. L., and Pye, K. (1992). Saltmarshes: Morphodynamics, Conservation, and Engineering Significance. Cambridge: Cambridge University Press.

Allen, S., O'Neill, C., Sowers, A., Weissberger, E., and Westby, S. (2013). Harris Creek Oyster Restoration Tributary Plan: A Blueprint to Restore the Oyster Population in Harris Creek, a tributary of the Choptank River on Maryland's Eastern Shore. Available online at: https://dnr.maryland.gov/fisheries/ Documents/Harris_Creek_tributary_plan_011513.pdf (accessed August 24, 2020).

Alsuwaiyan, N. A., Mohring, M. B., Cambridge, M., Coleman, M. A., Kendrick, G. A., and Wernberg, T. (2019). A review of protocols for the experimental release of kelp (Laminariales) zoospores. Ecol. Evol. 9, 8387-8398. doi: 10.1002/ ece3.5389

Babcock, R. C., Bull, G. D., Harrison, P. L., Heyward, A. J., Oliver, J. K., Wallace, C. C., et al. (1986). Synchronous spawnings of 105 scleractinian coral species on the Great Barrier Reef. Mar. Biol. 90, 379-394. doi: 10.1007/bf00428562

Baird, A. H., Guest, J. R., and Willis, B. L. (2009). Systematic and biogeographical patterns in the reproductive biology of scleractinian corals. Annu. Rev. Ecol. Evol. Syst. 40, 551-571. doi: 10.1146/annurev.ecolsys.110308.120220

Ballesteros, E., Cebrian, E., Garcia-Rubies, A., Alcoverro, T., Romero, J., and Font, X. (2005). Pseudovivipary, a new form of asexual reproduction in the seagrass Posidonia oceanica. Bot. Mar. 48, 175-177.

Baria-Rodriguez, M. V., Dela Cruz, D. W., Dizon, R. M., Yap, H. T., and Villanueva, R. D. (2019). Performance and cost-effectiveness of sexually produced Acropora granulosa juveniles compared with asexually generated coral fragments in restoring degraded reef areas. Aquat. Conserv. Mar. Freshw. Ecosyst. 29, 891900. doi: 10.1002 /aqc. 3132

Beck, M. W., Brumbaugh, R. D., Airoldi, L., Carranza, A., Coen, L. D., Crawford, C., et al. (2011). Oyster reefs at risk and recommendations for conservation, restoration, and management. Bioscience 61, 107-116. doi: 10.1525/bio.2011. 61.2 .5

Bekkby, T., Papadopoulou, N., Fiorentino, D., Mcowen, C. J., Rinde, E., Boström, C., et al. (2020). Habitat features and their influence on the restoration potential of marine habitats in Europe. Front. Mar. Sci. 7:184. doi: 10.3389/fmars.2020. 00184

Benedict, L., Linscombe, S. D., Wenefrida, I., and Utomo, H. S. (2012). Aerial planting of smooth cordgrass using a fixed-wing airplane and airboat. Louisiana Agric. 55, 6-8.

Boström-Einarsson, L., Babcock, R. C., Bayraktarov, E., Ceccarelli, D., Cook, N., Ferse, S. C. A., et al. (2020). Coral restoration - A systematic review of current methods, successes, failures and future directions. PLoS One 15:e0226631. doi: 10.1371/journal.pone.0226631

Breitburg, D. L., Coen, L. D., Luckenbach, M. W., Mann, R., Posey, M., and Wesson, J. A. (2000). Oyster reef restoration: convergence of harvest and conservation strategies. J. Shellfish Res. 19, 371-377.

Broome, S. W., Seneca, E. D., and Woodhouse, W. W. (1988). Tidal salt-marsh restoration. Aquat. Bot. 32, 1-22.

Broome, S. W., Woodhouse, W. W., and Seneca, E. D. (1974). Propagation of smooth cordgrass, Spartina alterniflora, from seed in North Carolina. Chesapeake Sci. 15, 214-221. doi: 10.2307/1350971

Brown, D. P., Basch, L., Barshis, D., Forsman, Z., Fenner, D., and Goldberg, J. (2009). American Samoa’s island of giants: massive Porites colonies at Tảu island. Coral Reefs 28, 735-735. doi: 10.1007/s00338-009-0494-8

Brumbaugh, R. D., Beck, M. W., Coen, L. D., Craig, L., and Hicks, P. (2006). A Practitioners Guide to the Design \& Monitoring of Shellfish Restoration Projects: An Ecosystem Services Approach. Arlington, VA: The Nature Conservancy.

Bruschetti, M. (2019). Role of reef-building, ecosystem engineering polychaetes in shallow water ecosystems. Diversity 11:168. doi: 10.3390/d11090168

Caley, M. J., Carr, M. H., Hixon, M. A., Hughes, T. P., Jones, G. P., and Menge, B. A. (1996). Recruitment and the local dynamics of open marine populations. Аnпu. Rev. Ecol. Syst. 27, 477-500. doi: 10.1146/annurev.ecolsys.27. 1.477
Camara, M. D., and Vadopalas, B. (2009). Genetic aspects of restoring Olympia oysters and other native bivalves: balancing the need for action, good intentions, and the risks of making things worse. J. Shellfish Res. 28, 121-145. doi: 10.2983/ 035.028.0104

Cameron, C., Hutley, L. B., Friess, D. A., and Brown, B. (2018). Community structure dynamics and carbon stock change of rehabilitated mangrove forests in Sulawesi, Indonesia. Ecol. Appl. 29:e01810.

Campbell, A. H., Marzinelli, E. M., Vergés, A., Coleman, M. A., and Steinberg, P. D. (2014). Towards restoration of missing underwater forests. PLoS One 9:e84106. doi: 10.1371/journal.pone.0084106

Campbell, M. L. (2016). Burial duration and frequency influences resilience of differing propagule types in a subtidal seagrass, Posidonia australis. PLoS One 11:e0161309. doi: 10.1371/journal.pone.0161309

Carney, L. T., Waaland, J. R., Klinger, T., and Ewing, K. (2005). Restoration of the bull kelp Nereocystis luetkeana in nearshore rocky habitats. Mar. Ecol. Prog. Ser. 302, 49-61. doi: 10.3354/meps302049

Caughlin, T. T., De La Pena-Domene, M., and Martinez-Garza, C. (2019). Demographic costs and benefits of natural regeneration during tropical forest restoration. Ecol. Lett. 22, 34-44. doi: 10.1111/ele.13165

Chan, H. T., Chong, P. F., and Ng, T. P. (1988). Silviculture efforts in restoring mangroves in degraded coastal areas in Peninsular Malaysia. Galaxea 7, 307314.

Chang, E. R., Zozaya, E. L., Kuijper, D. P. J., and Bakker, J. P. (2005). Seed dispersal by small herbivores and tidal water: are they important filters in the assembly of salt-marsh communities? Funct. Ecol. 19, 665-673. doi: 10.1111/j.1365-2435. 2005.01011.x

Chavanich, S., Ussavauschariyakul, S., Viyakarn, V., and Fujita, T. (2014). Influence of mineral accretion induced by electric current on the settlement and growth of the scleractinian coral Pocillopora damicornis (Cnidaria, Anthozoa, Hexacorallia). Mar. Res. Indones. 38, 89-94. doi: 10.14203/mri.v38i2.60

Chowdhury, A., Naz, A., and Bhattacharyya, S. (2019). "Plantation methods and restoration techniques for enhanced blue carbon sequestration by mangroves," in Carbon Sequestration Vol. 1 Introduction and Biochemical Methods. Sustainable Agriculture Reviews 37, eds Inamuddin, A. M. Asiri, and E. Lichtfouse (Cham: Springer Nature), 127-144. doi: 10.1007/978-3-030-292980_7

Clarke, P. J., and Kerrigan, R. A. (2002). The effects of seed predators on the recruitment of mangroves. J. Ecol. 90, 728-736. doi: 10.1046/j.1365-2745.2002. 00705.x

Coen, L. D., and Luckenbach, M. W. (2000). Developing success criteria and goals for evaluating oyster reef restoration: ecological function or resource exploitation? Ecol. Eng. 15, 323-343. doi: 10.1016/s0925-8574(00)00084-7

Cohen-Shacham, E., Walters, G., Janzen, C., and Maginnis, S. (2016). Nature-based Solutions to Address Global Societal Challenges. Gland: IUCN.

Coleman, M., Wood, G., Filbee-Dexter, K., Minne, A., Goold, H., Vergés, A., et al. (2020). Restore or redefine: future trajectories for marine forest restoration. Front. Mar. Sci. 7:237. doi: 10.3389/fmars.2020.00237

Coleman, M. A., and Goold, H. D. (2019). Harnessing synthetic biology for kelp forest conservation. J. Phycol. 55, 745-751. doi: 10.1111/jpy.12888

de la Cruz, D. W., and Harrison, P. L. (2017). Enhanced larval supply and recruitment can replenish reef corals on degraded reefs. Sci. Rep. 7:13985.

de Melo, C. M. R., Durland, E., and Langdon, C. (2016). Improvements in desirable traits of the Pacific oyster, Crassostrea gigas, as a result of five generations of selection on the West Coast, USA. Aquaculture 460, 105-115. doi: 10.1016/j. aquaculture.2016.04.017

Department of Environment and Climate Change (2008). Best Practice Guidelines for Coastal Saltmarsh. Sydney: Department of Environment and Climate Change NSW.

Deysher, L. E., Dean, T. A., Grove, R. S., and Jahn, A. (2002). Design considerations for an artificial reef to grow giant kelp (Macrocystis pyrifera) in Southern California. ICES J. Mar. Sci. 59, S201-S207.

Doropoulos, C., and Babcock, R. C. (2018). Harnessing connectivity to facilitate coral restoration. Front. Ecol. Environ. 16, 558-559. doi: 10.1002/fee.1975

Doropoulos, C., Elzinga, J., Ter Hofstede, R., Van Koningsveld, M., and Babcock, R. C. (2019a). Optimizing industrial-scale coral reef restoration: comparing harvesting wild coral spawn slicks and transplanting gravid adult colonies. Restor. Ecol. 27, 758-767. doi: 10.1111/rec.12918 
Doropoulos, C., Roff, G., Bozec, Y.-M., Zupan, M., Werminghausen, J., and Mumby, P. J. (2016). Characterizing the ecological trade-offs throughout the early ontogeny of coral recruitment. Ecol. Monogr. 86, 20-44.

Doropoulos, C., Vons, F., Elzinga, J., Ter Hofstede, R., Salee, K., Van Koningsveld, M., et al. (2019b). Testing industrial-scale coral restoration techniques: harvesting and culturing wild coral-spawn slicks. Front. Mar. Sci. 6:658. doi: 10.3389/fmars.2019.00658

Duke, N. C. (1992). "Mangrove Floristics and Biogeography," in Tropical Mangrove Ecosystems, eds A. I. Robertson and D. M. Alongi (Washington, DC: American Geophysical Union), 63-100. doi: 10.1029/ce041p0063

Edwards, A. J. (ed). (2010). Reef Rehabilitation Manual. Saint Lucia, LCA: Coral Reef Targeted Research \& Capacity Building for Management Program, 1-166.

Edwards, A. J., and Clark, S. (1999). Coral transplantation: a useful management tool or misguided meddling? Mar. Pollut. Bull. 37, 474-487. doi: 10.1016/ s0025-326x(99)00145-9

Edwards, A. J., Guest, J. R., Heyward, A. J., Villanueva, R. D., Baria, M. V., Bollozos, I. S., et al. (2015). Direct seeding of mass-cultured coral larvae is not an effective option for reef rehabilitation. Mar. Ecol. Prog. Ser. 525, 105-116. doi: 10.3354/meps11171

Eganathan, P., Srinivasa Rao, C., and Anand, A. (2000). Vegetative propagation of three mangrove tree species by cuttings and air layering. Wetl. Ecol. Manage. 8, 281-286.

Ermgassen, P., Spalding, M. D., Blake, B., Coen, L. D., Dumbauld, B., Geiger, S., et al. (2012). Historical ecology with real numbers: past and present extent and biomass of an imperilled estuarine habitat. Proc. Biol. Sci. 279, 3393-3400. doi: $10.1098 / \mathrm{rspb} .2012 .0313$

Falace, A., Kaleb, S., De La Fuente, G., Asnaghi, V., and Chiantore, M. (2018). Ex situ cultivation protocol for Cystoseira amentacea var. stricta (Fucales, Phaeophyceae) from a restoration perspective. PLoS One 13:e0193011. doi: 10.1371/journal.pone.0193011

Falace, A., Zanelli, E., and Bressan, G. (2006). Algal transplantation as a potential tool for artificial reef management and environmental mitigation. Bull. Mar. Sci. 78, 161-166.

Ferse, S. C., Nugues, M. M., Romatzki, S. B., and Kunzmann, A. (2013). Examining the use of mass transplantation of brooding and spawning corals to support natural coral recruitment in Sulawesi/Indonesia. Restor. Ecol. 21, 745-754. doi: $10.1111 /$ rec. 12004

Filbee-Dexter, K., and Wernberg, T. (2018). Rise of turfs: a new battlefront for globally declining kelp forests. Bioscience 68, 64-76. doi: 10.1093/biosci/bix147

Fonseca, M. S. (1998). Guidelines for the Conservation and Restoration of Seagrasses in the United States and Adjacent Waters. Washington, DC: US Department of Commerce.

Forêt, M., Barbier, P., Tremblay, R., Meziane, T., Neumeier, U., Duvieilbourg, E., et al. (2018). Trophic cues promote secondary migrations of bivalve recruits in a highly dynamic temperate intertidal system. Ecosphere 9:e02510. doi: $10.1002 /$ ecs 2.2510

Foster, M. S., and Schiel, D. R. (2010). Loss of predators and the collapse of southern California kelp forests (?): alternatives, explanations and generalizations. J. Exp. Mar. Biol. Ecol. 393, 59-70. doi: 10.1016/j.jembe.2010.07.002

Fredriksen, S., Filbee-Dexter, K., Norderhaug, K. M., Steen, H., Bodvin, T., Coleman, M. A., et al. (2020). Green gravel: a novel restoration tool to combat kelp forests decline. Sci. Rep. 10:3983.

Friess, D. A., Rogers, K., Lovelock, C. E., Krauss, K. W., Hamilton, S. E., Lee, S. Y., et al. (2019). The state of the world's mangrove forests: past, present, and future. Annu. Rev. Environ. Resour. 44, 89-115.

Gaylord, B., Reed, D. C., Raimondi, P. T., Washburn, L., and Mclean, S. R. (2002). A physically based model of macroalgal spore dispersal in the wave and currentdominated nearshore. Ecology 83, 1239-1251. doi: 10.1890/0012-9658(2002) 083[1239:apbmom]2.0.co;2

Ge, Z. M., Li, S. H., Tan, L. S., Li, Y. L., and Hui, Z. J. (2019). The importance of the propagule-sediment-tide "power balance" for revegetation at the coastal frontier. Ecol. Appl. 29:e01967.

Gillies, C. L., Crawford, C., and Hancock, B. (2017). Restoring Angasi oyster reefs: what is the endpoint ecosystem we are aiming for and how do we get there? Ecol. Manage. Restor. 18, 214-222. doi: 10.1111/emr.12278

Goddard, M. (2009). "Fitness traits in animal breeding programs," in Adaptation and Fitness in Animal Populations, eds J. Van Der Werf, H.-U. Graser, R.
Frankham, and C. Gondro (Dordrecht: Springer), 41-52. doi: 10.1007/978-14020-9005-9_3

Goreau, T. J. (2014). Electrical stimulation greatly increases settlement, growth, survival, and stress resistance of marine organisms. Nat. Resour. 5, 527-537. doi: $10.4236 / \mathrm{nr} .2014 .510048$

Goreau, T. J., and Prong, P. (2017). Biorock electric reefs grow back severely eroded beaches in months. J. Mar. Sci. Eng. 5:48. doi: 10.3390/jmse5040048

Gorman, D., and Connell, S. D. (2009). Recovering subtidal forests in humandominated landscapes. J. Appl. Ecol. 46, 1258-1265. doi: 10.1111/j.1365-2664. 2009.01711.x

Guest, J., Baria, M., Gomez, E., Heyward, A., and Edwards, A. (2014). Closing the circle: is it feasible to rehabilitate reefs with sexually propagated corals? Coral Reefs 33, 45-55. doi: 10.1007/s00338-013-1114-1

Hai, N. T., Dell, B., Phuong, V. T., and Harper, R. J. (2020). Towards a more robust approach for the restoration of mangroves in Vietnam. Ann. For. Sci. $77: 18$.

Haraguchi, H., Tanaka, K., Imoto, Z., and Hiraoka, M. (2009). The decline of Ecklonia cava in Kochi, Japan and challenge in marine afforestation. Kuroshio Sci. 3, 49-54.

Harding, J. M., and Mann, R. (2001). Oyster reefs as fish habitat: opportunistic use of restored reefs by transient fishes. J. Shellfish Res. 20, 951-959.

Hargis, W. J. Jr., and Haven, D. S. (1999). "Chesapeake oyster reefs, their importance, destruction and guidelines for restoring them," in Oyster Reef Habitat Restoration: A Synopsis and Synthesis of Approaches, eds M. W. Luckenbach, R. Mann, and J. Wesson (Gloucester Point, VA: Virginia Institute of Marine Science Press), 329-358.

Harriott, V. J. (1983). Reproductive ecology of four scleratinian species at Lizard Island, Great Barrier Reef. Coral Reefs 2, 9-18. doi: 10.1007/bf00304727

Harrison, P. L., and Wallace, C. C. (1990). "Reproduction, dispersal and recruitment of scleractinian corals," in Coral Reefs, ed. Z. Dubinsky (Amsterdam: Elsevier Science), 133-207.

Harwell, M. C., and Orth, R. J. (2002). Long-distance dispersal potential in a marine macrophyte. Ecology 83, 3319-3330. doi: 10.1890/0012-9658(2002)083[3319: lddpia]2.0.co;2

Hernández-Carmona, G., García, O., Robledo, D., and Foster, M. (2000). Restoration techniques for Macrocystis pyrifera (Phaeophyceae) populations at the southern limit of their distribution in México. Bot. Mar. 43:273.

Hernández-Carmona, G., Hughes, B., and Graham, M. H. (2006). Reproductive longevity of drifting kelp Macrocystis pyrifera (Phaeophyceae) in Monterey Bay, USA. J. Phycol. 42, 1199-1207. doi: 10.1111/j.1529-8817.2006.00290.x

Heyward, A. J., Smith, L. D., Rees, M., and Field, S. N. (2002). Enhancement of coral recruitment by in situ mass culture of coral larvae. Mar. Ecol. Prog. Ser. 230, 113-118. doi: 10.3354/meps 230113

Highsmith, R. C. (1982). Reproduction by fragmentation in corals. Mar. Ecol. Prog. Ser. 7, 207-226. doi: 10.3354/meps007207

Huiskes, A. H. L., Koutstaal, B. P., Herman, P. M. J., Beeftink, W. G., Markusse, M. M., and Demunck, W. (1995). Seed dispersal of halophytes in tidal salt marshes. J. Ecol. 83, 559-567. doi: 10.2307/2261624

Inglis, G. J. (2000). Disturbance-related heterogeneity in the seed banks of a marine angiosperm. J. Ecol. 88, 88-99. doi: 10.1046/j.1365-2745.2000.00433.x

Jones, G., Almany, G., Russ, G., Sale, P., Steneck, R., Van Oppen, M., et al. (2009). Larval retention and connectivity among populations of corals and reef fishes: history, advances and challenges. Coral Reefs 28, 307-325. doi: 10.1007/s00338009-0469-9

Joska, M. A. P., and Bolton, J. J. (1987). In situ Measurement of Zoospore Release and Seasonality of Reproduction in Ecklonia maxima (Alariaceae, Laminariales). Br. Phycol. J. 22, 209-214. doi: 10.1080/00071618700650251

Kathiresan, K., and Bingham, B. L. (2001). Biology of mangroves and mangrove ecosystems. Adv. Mar. Biol. 40, 81-251. doi: 10.1016/s0065-2881(01)40003-4

Kendrick, G. A., Orth, R. J., Statton, J., Hovey, R., Ruiz Montoya, L., Lowe, R. J., et al. (2017). Demographic and genetic connectivity: the role and consequences of reproduction, dispersal and recruitment in seagrasses. Biol. Rev. 92, 921-938. doi: 10.1111/brv.12261

Kendrick, G. A., and Walker, D. I. (1991). Dispersal distances for propagules of Sargassum spinuligerum Sargassaceae Phaeophyta measured directly by vital staining and venturi suction sampling. Mar. Ecol. Prog. Ser. 79, 133-138. doi: 10.3354/meps079133 
Kendrick, G. A., Waycott, M., Carruthers, T. J., Cambridge, M. L., Hovey, R., Krauss, S. L., et al. (2012). The central role of dispersal in the maintenance and persistence of seagrass populations. Bioscience 62, 56-65. doi: 10.1525/bio.2012. 62.1 .10

Kirkman, H. (1999). Pilot experiments on planting seedlings and small seagrass propagules in Western Australia. Mar. Pollut. Bull. 37, 460-467. doi: 10.1016/ s0025-326x (99)00146-0

Knutson, P. L. (1977). Planting guidelines for marsh development and bank stabilization. Coastal Engineering Technical Aid No. 77-3. Virginia, VA: United States Army, Corps of Engineers.

Kojis, B. L. (1986). Sexual reproduction in Acropora (Isopora) species (Ceolenterata, Scleractinia). 1. Acropora cuneata and Acropora palifera on Heron Island Reef, Great Barrier Reef. Mar. Biol. 91, 291-309. doi: $10.1007 / \mathrm{bf} 00428623$

Kuo, J., and den Hartog, C. (2006). "Seagrass morphology, anatomy, and ultrastructure," in Seagrasses: Biology, Ecology and Conservation, eds A. W. D. Larkum, R. J. Orth, and C. E. Duarte (Dordrecht: Springer), 51-87. doi: 10.1007/ 978-1-4020-2983-7_3

Lacap, C. D. A., Vermaat, J. E., Rollon, R. N., and Nacorda, H. M. (2002). Propagule dispersal of the SE Asian seagrasses Enhalus acoroides and Thalassia hemprichii. Mar. Ecol. Prog. Ser. 235, 75-80. doi: 10.3354/meps 235075

Ladd, M. C., Burkepile, D. E., and Shantz, A. A. (2019). Near-term impacts of coral restoration on target species, coral reef community structure, and ecological processes. Restor. Ecol. 27, 1166-1176. doi: 10.1111/rec.12939

Layton, C., Coleman, M., Marzinelli, E., Steinberg, P., Swearer, S., Vergés, A., et al. (2018). Restoring Kelp Habitat in Australia, in (McLeod I.M., Boström-Einarsson L., Johnson C.R., Kendrick G., Layton C., Rogers A.A., Statton J. (2018). The Role of Restoration in Conserving Matters of National Environmental Significance. Report to the National Environmental Science Programme (Canberra: Marine Biodiversity Hub).

Layton, C., Coleman, M. A., Marzinelli, E. M., Steinberg, P. D., Swearer, S. E., Vergés, A., et al. (2020). Kelp forest restoration in Australia. Front. Mar. Sci. 7:74. doi: 10.3389/fmars.2020.00074

Leal, I., Bouchard, É., Flores, A. A., and Tremblay, R. (2018). Trophic cues as possible triggers of mussel larval settlement in southeastern Brazil. Aquat. Living Resour. 31:26. doi: 10.1051/alr/2018013

Les, D. H., Cleland, M. A., and Waycott, M. (1997). Phylogenetic studies in Alismatidae, II: evolution of marine angiosperms (seagrasses) and hydrophily. Syst. Bot. 443-463. doi: 10.2307/2419820

Lewis Iii, R. R., and Brown, B. (2014). Ecological Mangrove Rehabilitation: A Field Manual for Practitioners. Available online at: www.mangroverestoration.com (accessed May 7, 2014).

Li, L. P., Cadotte, M. W., Martinez-Garza, C., De La Pena-Domene, M., and Du, G. Z. (2018). Planting accelerates restoration of tropical forest but assembly mechanisms appear insensitive to initial composition. J. Appl. Ecol. 55, 986-996. doi: 10.1111/1365-2664.12976

Lovelock, C. E., Cahoon, D. R., Friess, D. A., Guntenspergen, G. R., Krauss, K. W., Reef, R., et al. (2015). The vulnerability of Indo-Pacific mangrove forests to sea-level rise. Nature 526, 559-563. doi: 10.1038/nature15538

Madin, J. S., Hoogenboom, M. O., Connolly, S. R., Darling, E. S., Falster, D. S., Huang, D., et al. (2016). A trait-based approach to advance coral reef science. Trends Ecol. Evol. 31, 419-428. doi: 10.1016/j.tree.2016.02.012

Maida, M., Sammarco, P. W., and Coll, J. C. (1995). Effects of soft corals on scleractinian coral recruitment. 1. Directional allelopathy and inhibition of settlement. Mar. Ecol. Prog. Ser. 121, 191-202. doi: 10.3354/meps121191

Mann, R. (2000). Restoring the oyster reef communities in the Chesapeake Bay: a commentary. J. Shellfish Res. 19, 335-339.

Maragos, J. E. (1974). Coral Transplantation: A Method to Create, Preserve, and Manage Coral Reefs. Hawaii University Sea Grant Advanced Report. Honolulu, HI: Hawaii University System.

McDonald, T., Gann, G. G., Jonson, J., and Dixon, K. W. (2016). International Standards for the Practice of Ecological Restoration-Including Principles and Key Concepts. Washington, DC: Society for Ecological Restoration.

Mcleod, E., Chmura, G. L., Bouillon, S., Salm, R., Bjork, M., Duarte, C. M., et al. (2011). A blueprint for blue carbon: toward an improved understanding of the role of vegetated coastal habitats in sequestering CO2. Front. Ecol. Environ. 9, 552-560. doi: $10.1890 / 110004$
Milano, G. (1999). Restoration of coastal wetlands in southeastern Florida. Wetl. J. $11,15-24$.

Montoya-Maya, P. H., Smit, K. P., Burt, A. J., and Frias-Torres, S. (2016). Largescale coral reef restoration could assist natural recovery in Seychelles, Indian Ocean. Nat. Conserv. 16, 1-17. doi: 10.3897/natureconservation.16.8604

Moore, K. A., Orth, R. J., and Nowak, J. F. (1993). Environmental regulation of seed germination in Zostera marina L.(eelgrass) in Chesapeake Bay: effects of light, oxygen and sediment burial. Aquat. Bot. 45, 79-91. doi: 10.1016/0304-3770(93) 90054-z

Mumby, P. J., Hastings, A., and Edwards, H. J. (2007). Thresholds and the resilience of Caribbean coral reefs. Nature 450, 98-101. doi: 10.1038/nature06252

Nelson, W. A. (2009). Calcified macroalgae - critical to coastal ecosystems and vulnerable to change: a review. Mar. Freshw. Res. 60, 787-801. doi: 10.1071/ mf08335

Norton, T. A., and Deysher, L. E. (1989). "The reproductive ecology of Sargassum muticum at different lattitudes," in Reproduction, Genetics and Distributions of Marine Organisms: 23rd European Marine Biology Symposium, School of Biological Sciences, eds J. S. Ryland and P. A. Tyler (Swansea: University of Wales), 147-152.

Oliver, J. K., and Willis, B. L. (1987). Coral-spawn slicks in the Great Barrier Reef preliminary observations. Mar. Biol. 94, 521-529. doi: 10.1007/bf00431398

Omori, M. (2019). Coral restoration research and technical developments: what we have learned so far. Mar. Biol. Res. 15:377. doi: 10.1080/17451000.2019.1662050

Omori, M., and Iwao, K. (2014). Methods of Farming Sexually Propagated Corals and Outplanting for Coral Reef Rehabilitation; with List of References for Coral Reef Rehabilitation Through Active Restoration Measure. Okinawa: Akajima Marine Science Laboratory.

Orth, R. J., Fishman, J. R., Harwell, M. C., and Marion, S. R. (2003). Seed-density effects on germination and initial seedling establishment in eelgrass Zostera marina in the Chesapeake Bay region. Mar. Ecol. Prog. Ser. 250, 71-79. doi: 10.3354/meps 250071

Orth, R. J., Harwell, M. C., Bailey, E. M., Bartholomew, A., Jawad, J. T., Lombana, A. V., et al. (2000). A review of issues in seagrass seed dormancy and germination: implications for conservation and restoration. Mar. Ecol. Prog. Ser. 200, 277-288. doi: 10.3354/meps200277

Orth, R. J., Luckenbach, M. L., Marion, S. R., Moore, K. A., and Wilcox, D. J. (2006). Seagrass recovery in the Delmarva coastal bays, USA. Aquat. Bot. 84, 26-36. doi: 10.1016/j.aquabot.2005.07.007

Orth, R. J., Marion, S. R., and Moore, K. A. (2007). A Summary of Eelgrass (Zostera marina) Reproductive Biology with an Emphasis on Seed Biology and Ecology from the Chesapeake Bay Region. Vicksburg, MS: U.S. Army Corps of Engineers.

Orth, R. J., Moore, K. A., Marion, S. R., Wilcox, D. J., and Parrish, D. B. (2012). Seed addition facilitates eelgrass recovery in a coastal bay system. Mar. Ecol. Prog. Ser. 448, 177-195. doi: 10.3354/meps09522

Page, C., and Vaughan, D. E. (2014). "The cultivation of massive corals using "micro-fragmentation" for the "reskinning" of degraded coral reefs," in Proceedings of the 43rd Benthic Ecology Meeting, Jacksonville, FL.

Pennings, S. C., and Callaway, R. M. (2000). The advantages of clonal integration under different ecological conditions: a community-wide test. Ecology 81, 709-716. doi: 10.1890/0012-9658(2000)081[0709:taociu]2.0.co;2

Petuha, E. T., Lundquist, C. J., and Pilditch, C. A. (2006). Estimating spatial scale of post-settlement transport potential of Macomona liliana on an intertidal sandflat. N. Z. J. Mar. Freshw. Res. 40, 487-502. doi: 10.1080/00288330.2006. 9517438

Pickerell, C. H., Schott, S., and Wyllie-Echeverria, S. (2005). Buoy-deployed seeding: demonstration of a new eelgrass (Zostera marina L.) planting method. Ecol. Eng. 25, 127-136. doi: 10.1016/j.ecoleng.2005.03.005

Pollock, F. J., Katz, S. M., Van De Water, J. A., Davies, S. W., Hein, M., Torda, G., et al. (2017). Coral larvae for restoration and research: a large-scale method for rearing Acropora millepora larvae, inducing settlement, and establishing symbiosis. PeerJ 5:e3732. doi: 10.7717/peerj.3732

Powers, S. P., Peterson, C. H., Grabowski, J. H., and Lenihan, H. S. (2009). Success of constructed oyster reefs in no-harvest sanctuaries: implications for restoration. Mar. Ecol. Prog. Ser. 389, 159-170. doi: 10.3354/meps08164

Primavera, J. H., Savaris, J. P., Bajoyo, B. E., Coching, J. D., Curnick, D. J., Golbeque, R. L., et al. (2012). Manual on Community-Based Mangrove Rehabilitation: Mangrove Manual Series No. 1. London: The Zoological Society of London. 
Rabinowitz, D. (1978). Mortality and initial propagule size in mangrove seedlings in panama. J. Ecol. 66, 45-51. doi: 10.2307/2259180

Reed, D. C. (1990). The effects of variable settlement and early competition on patterns of kelp recruitment. Ecology 71, 776-787. doi: 10.2307/1940329

Reed, D. C., Amsler, C. D., and Ebeling, A. W. (1992). Dispersal in kelps: factors affecting spore swimming and competency. Ecology 73, 1577-1585. doi: 10. 2307/1940011

Richards, C. L., Hamrick, J. L., Donovan, L. A., and Mauricio, R. (2004). Unexpectedly high clonal diversity of two salt marsh perennials across a severe environmental gradient. Ecol. Lett. 7, 1155-1162. doi: 10.1111/j.1461-0248. 2004.00674.x

Rinkevich, B. (1995). Restoration strategies for coral reefs damaged by recreational activities: the use of sexual and asexual recruits. Restor. Ecol. 3, 241-251. doi: 10.1111/j.1526-100x.1995.tb00091.x

Robertshaw, G., Nedosyko, A., and Bayram, A. (2019). "Windara Reef-lessons learnt from the first large scale oyster reef restoration in Australia," in Proceedings of the Australasian Coasts and Ports 2019 Conference: Future Directions from 40 [degrees] S and Beyond, Hobart, 996.

Saenger, P., and Siddiqi, N. A. (1993). Land from the Sea: the mangrove afforestation program of Bangladesh. Ocean Coast. Manage. 20, 23-39. doi: 10.1016/0964-5691(93)90011-m

Seddon, N., Chausson, A., Berry, P., Girardin, C. A. J., Smith, A., and Turner, B. (2020). Understanding the value and limits of nature-based solutions to climate change and other global challenges. Philos. Trans. R. Soc. Lond. B Biol. Sci. 375:20190120. doi: 10.1098/rstb.2019.0120

Shafir, S., Van Rijn, J., and Rinkevich, B. (2006). Steps in the construction of underwater coral nursery, an essential component in reef restoration acts. Mar. Biol. 149, 679-687. doi: 10.1007/s00227-005-0236-6

Shelamoff, V., Layton, C., Tatsumi, M., Cameron, M. J., Wright, J. T., and Johnson, C. R. (2019). Ecosystem engineering by a canopy-forming kelp facilitates the recruitment of native oysters. Restor. Ecol. 27, 1442-1451. doi: 10.1111/rec. 13019

Short, F., Carruthers, T., Dennison, W., and Waycott, M. (2007). Global seagrass distribution and diversity: a bioregional model. J. Exp. Mar. Biol. Ecol. 350, 3-20. doi: 10.1016/j.jembe.2007.06.012

Sigurdsson, J. B., Titman, C., and Davies, P. A. (1976). The dispersal of young postlarval bivalve molluscs by byssus threads. Nature 262, 386-387. doi: 10.1038/ $262386 \mathrm{a} 0$

Sinclair, E. A., Statton, J., Hovey, R., Anthony, J. M., Dixon, K. W., and Kendrick, G. A. (2016). Reproduction at the extremes: pseudovivipary, hybridization and genetic mosaicism in Posidonia australis (Posidoniaceae). Ann. Bot. 117, 237-247.

Soons, M. B. (2006). Wind dispersal in freshwater wetlands: knowledge for conservation and restoration. Appl. Veg. Sci. 9, 271-278. doi: 10.1111/j.1654109x.2006.tb00676.x

Spalding, M. D., Mcivor, A. L., Beck, M. W., Koch, E. W., Moller, I., Reed, D. J., et al. (2014). Coastal ecosystems: a critical element of risk reduction. Conserv. Lett. 7, 293-301. doi: 10.1111/conl.12074

Spurgeon, J. (1998). The socio-economic costs and benefits of coastal habitat rehabilitation and creation. Mar. Pollut. Bull. 37, 373-382. doi: 10.1016/s0025$326 \mathrm{x}(99) 00074-0$

Staples, T. L., Mayfield, M. M., England, J. R., and Dwyer, J. M. (2020). Comparing the recovery of richness, structure, and biomass in naturally regrowing and planted reforestation. Restor. Ecol. 28, 347-357. doi: 10.1111/rec.13077

Statton, J., Cambridge, M. L., Dixon, K. W., and Kendrick, G. A. (2013). Aquaculture of Posidonia australis seedlings for seagrass restoration programs: effect of sediment type and organic enrichment on growth. Restor. Ecol. 21, 250-259. doi: 10.1111/j.1526-100x.2012.00873.x

Statton, J., Dixon, K. W., Hovey, R. K., and Kendrick, G. A. (2012). A comparative assessment of approaches and outcomes for seagrass revegetation in Shark Bay and Florida Bay. Mar. Freshw. Res. 63, 984-993. doi: 10.1071/mf12032

Statton, J., Montoya, L. R., Orth, R. J., Dixon, K. W., and Kendrick, G. A. (2017). Identifying critical recruitment bottlenecks limiting seedling establishment in a degraded seagrass ecosystem. Sci. Rep. 7:14786.

Strydom, S., Mcmahon, K., and Lavery, P. S. (2017). Response of the seagrass Halophila ovalis to altered light quality in a simulated dredge plume. Mar. Pollut. Bull. 121, 323-330. doi: 10.1016/j.marpolbul.2017.05.060
Sturmer, J. (2017). Climate Change in Drones' Sights with Ambitious Plan to Remotely Plant Nearly 100,000 Trees a Day. Available online at: http://mobile.abc.net.au/news/2017-06-25/the-plan-to-plant-nearly-100, 000-trees-a-day-with-drones/8642766 (accessed 08 July 2017).

Suggett, D. J., Edmondson, J., Howlett, L., and Camp, E. F. (2020). Coralclip ${ }^{\circledR}$ : a low-cost solution for rapid and targeted out-planting of coral at scale. Restor. Ecol. 28, 289-296. doi: 10.1111/rec.13070

Sully, S., Burkepile, D. E., Donovan, M. K., Hodgson, G., and Van Woesik, R. (2019). A global analysis of coral bleaching over the past two decades. Nat. Commun. 10:1264.

Tanner, J. E. (2015). Restoration of the seagrass Amphibolis antarctica-temporal variability and long-term success. Estuaries Coasts 38, 668-678. doi: 10.1007/ s12237-014-9823-4

Terawaki, T., Hasegawa, H., Arai, S., and Ohno, M. (2001). Management-free techniques for restoration of Eisenia and Ecklonia beds along the central Pacific coast of Japan. J. Appl. Phycol. 13, 13-17.

Todd, P. A. (2008). Morphological plasticity in scleractinian corals. Biol. Rev. 83, 315-337. doi: 10.1111/j.1469-185x.2008.00045.x

Tomlinson, P. B. (2016). The Botany of Mangroves, 2nd Edn. Cambridge: Cambridge University Press.

Toupoint, N., Mohit, V., Linossier, I., Bourgougnon, N., Myrand, B., Olivier, F., et al. (2012). Effect of biofilm age on settlement of Mytilus edulis. Biofouling 28, 985-1001. doi: $10.1080 / 08927014.2012 .725202$

US Environmental Protection Agency (1979). An Ecological Characterization Study of the Chenier Plain Coastal Ecosystem of Louisiana and Texas. Volume 1. Narrative Report. Washington, DC: US Environmental Protection Agency.

Valdez, S. R., Zhang, Y. S., Van Der Heide, T., Vanderklift, M. A., Tarquinio, F., Orth, R. J., et al. (2020). Positive ecological interactions and the success of seagrass restoration. Front. Mar. Sci. 7:91. doi: 10.3389/fmars.2020.00091

van Katwijk, M. M., Thorhaug, A., Marbà, N., Orth, R. J., Duarte, C. M., Kendrick, G. A., et al. (2016). Global analysis of seagrass restoration: the importance of large-scale planting. J. Appl. Ecol. 53, 567-578. doi: 10.1111/1365-2664.12562

van Oppen, M. J. H., Gates, R. D., Blackall, L. L., Cantin, N., Chakravarti, L. J., Chan, W. Y., et al. (2017). Shifting paradigms in restoration of the world's coral reefs. Glob. Change Biol. 23, 3437-3448.

Verdura, J., Sales, M., Ballesteros, E., Cefalì, M. E., and Cebrian, E. (2018). Restoration of a canopy-forming alga based on recruitment enhancement: methods and long-term success assessment. Front. Plant Sci. 9:1832. doi: 10. $3389 /$ fpls.2018.01832

Veron, J. (2013). Overview of the taxonomy of zooxanthellate Scleractinia. Zool. J. Linn. Soc. 169, 485-508. doi: 10.1111/zoj.12076

Viviansmith, G., and Stiles, E. W. (1994). Dispersal of salt-marsh seeds on the feet and feathers of waterfowl. Wetlands 14, 316-319. doi: 10.1007/bf03160638

Wang, W., Li, X., and Wang, M. (2019). Propagule dispersal determines mangrove zonation at intertidal and estuarine scales. Forests 10:245. doi: 10.3390/ f10030245

Waycott, M., Duarte, C. M., Carruthers, T. J. B., Orth, R. J., Dennison, W. C., Olyarnik, S., et al. (2009). Accelerating loss of seagrasses across the globe threatens coastal ecosystems. Proc. Natl. Acad. Sci. U.S.A. 106, 12377-12381. doi: 10.1073/pnas.0905620106

Wernberg, T., and Filbee-Dexter, K. (2019). Missing the marine forest for the trees. Mar. Ecol. Prog. Ser. 612, 209-215. doi: 10.3354/meps 12867

Wernberg, T., Krumhansl, K., Filbee-Dexter, K., and Pedersen, M. (2019). "Status and trends for the world's kelp forests," in World Seas: An Environmental Evaluation, 2nd Edn, ed. C. Sheppard (London: Elsevier), 57-78. doi: 10.1016/ b978-0-12-805052-1.00003-6

Westby, S., Geselbracht, L., and Pogoda, B. (2019). "Shellfish reef restoration in practice," in Restoration Guidelines for Shellfish Reefs, eds J. Fitzsimons, S. Branigan, R. Brumbaugh, T. McDonald and P. zu Ermgassen (Arlington, VA: The Nature Conservancy), 36-48.

Williams, S. L., Sur, C., Janetski, N., Hollarsmith, J. A., Rapi, S., Barron, L., et al. (2019). Large-scale coral reef rehabilitation after blast fishing in Indonesia. Restor. Ecol. 27, 447-456. doi: 10.1111/rec.12866

Wilson, K. C., and North, W. J. (1983). A review of kelp bed management in southern California. J. World Aquacult. Soc. 14, 345-359. doi: 10.1111/j.17497345.1983.tb00089.x 
Wood, A. C. L., Probert, P. K., Rowden, A. A., and Smith, A. M. (2012). Complex habitat generated by marine bryozoans: a review of its distribution, structure, diversity, threats and conservation. Aquat. Conserv. Mar. Freshw. Ecosyst. 22, 547-563. doi: 10.1002/aqc.2236

Wulff, J. (2012). "Ecological interactions and the distribution, abundance, and diversity of sponges," in Advances in Sponge Science: Phylogeny, Systematics, Ecology, eds M. A. Becerro, M. J. Uriz, M. Maldonado, and X. Turon (Oxford: Academic Press), 273-344. doi: 10.1016/b978-0-12-387787-1.00003-9

Zhang, Q., Qiu, S. Y., Zhu, Y., Cui, X. H., He, Q., and Li, B. (2020). Propagule types and environmental stresses matter in saltmarsh plant restoration. Ecol. Eng. 143:7.
Conflict of Interest: The authors declare that the research was conducted in the absence of any commercial or financial relationships that could be construed as a potential conflict of interest.

Copyright (C) 2020 Vanderklift, Doropoulos, Gorman, Leal, Minne, Statton, Steven and Wernberg. This is an open-access article distributed under the terms of the Creative Commons Attribution License (CC BY). The use, distribution or reproduction in other forums is permitted, provided the original author(s) and the copyright owner(s) are credited and that the original publication in this journal is cited, in accordance with accepted academic practice. No use, distribution or reproduction is permitted which does not comply with these terms. 